\title{
TENDENSI PROSES KONVERGENSI DAN PENENTU PERTUMBUHAN EKONOMI WILAYAH PULAU UTAMA DI INDONESIA, 1985-2010
}

\section{Tendency of Convergence Process and Determinant of Economic Growth of Main Island Regions in Indonesia, 1985-2010}

\author{
Tajerin'1, Akhmad Fauzi², Bambang Juanda² dan Luky Adrianto ${ }^{3}$ \\ ${ }^{1}$ Balai Besar Penelitian Sosial Ekonomi Kelautan dan Perikanan \\ JI. KS. Tubun Petamburan VI Jakarta 10260 \\ Telp. (021) 53650162, Fax. (021)53650159 \\ 2Dosen Fakultas IImu Ekonomi dan Manajemen, Institu Pertanian Bogor \\ ${ }^{3}$ Dosen Fakultas Perikanan dan IImu Kelautan, Institu Pertanian Bogor \\ Email: jerin_jmhr@yahoo.com \\ Diterima 28 Mei 2013 - Disetujui 22 Nopember 2013
}

\begin{abstract}
ABSTRAK
Ketimpangan ekonomi antar wilayah pulau utama di Indonesia merupakan sesuatu yang secara alamiah akan terjadi. Hal ini karena, sebagai negara kepulauan, Indonesia memiliki enam wilayah pulau utama dengan karakteristik yang berbeda, yang tentunya akan menyebabkan pola pembangunan dan tingkat kemampuan tumbuh yang berbeda pula. Penelitian ini bertujuan: (1) Menganalisis tendensi proses konvergensi ekonomi antar wilayah pulau utama, dan; (2) Menduga faktor penentu pertumbuhan ekonomi wilayah pulau utama dan konrtibusinya terhadap tendensi konvergensi. Penelitian dilakukan menggunakan unit analisis wilayah pulau utama dan data sekunder periode 1985-2010 yang dianalisis dengan pendekatan ekonometrika model data panel. Hasil penelitian mununjukkan bahwa tendensi proses konvergensi ekonomi wilayah pulau utama di Indonesia selama periode analisis telah terjadi namun berlangsung lambat dengan kecepatan konvergensi ekonomi sebesar 3,22-8,50\% per tahun (secara kondisional). Berdasarkan model fixed-effect, peubah modal fisik dan modal manusia berpengaruh positif terhadap tingkat pertumbuhan PDRB per kapita kondisi mapan. Sementara peubah resultan dari pertumbuhan penduduk dan penyusutan modal berpengaruh negatif terhadap tingkat pertumbuhan PDRB per kapita kondisi mapan. Dengan mengontrol peubah-peubah penentu pertumbuhan ekonomi, mampu mendorong kecepatan tendensi proses konvergensi meningkat sebesar 1,56-4,75\% per tahun dengan half-life time 10,34-31,76 tahun. Hal ini berarti bahwa untuk mempercepat konvergensi ekonomi antar wilayah utama Indonesia dibutuhkan peningkatan modal fisik dan modal manusia yang terdistribusi secara lebih merata, dan diikuti pengendalian pertumbuhan penduduk dan penyusutan modal. Mengingat bahwa wilayah pulau utama di Indonesia memiliki sumberdaya kelautan yang besar, maka kebijakan untuk mempercepat konvergensi tersebut perlu diimplementasikan dengan mempertimbangkan peran kelautan yang disinergikan dengan upaya meningkatkan interrelasi (konektivitas) sektoral dan spasial antar wilayah di Indonesia.
\end{abstract}

Kata Kunci: konvergensi, pertumbuhan PDRB, wilayah pulau utama, data panels

\begin{abstract}
The economic disparity among the main island regions in Indonesia is a natural occurrence. Due to the fact that, as an archipelago, Indonesia is consisted of six main island regions, each with its own indigenous characteristic, thus generating different development patterns and different developing abilities. Therefore, a research has been done to: (1) Analyze the tendency of economic convergence process among the main island regions; and (2) Estimate the determinant factors of economic growth within the main island regions, as well as their contributions toward the convergence tendency. The research was conducted with the main island regions as the analysis unit, and secondary data covering a 25 years period, spanning from 1985 to 2010. The data acquired were analyzed using a data panel econometric model. The analysis resulted in a finding that there has been a convergence tendency among the main island regions in Indonesia during the period analyzed. The economic convergence rate found was considered low with an estimated rateper annum of 3,22\%-8,5\% (Conditionally). Based
\end{abstract}


on the fixed effect model, both physical and human capitals were the variables which positively affecting the growth of the steady state per capita Regional Gross Domestic Product. While population growth and capital depreciation were the variables which negatively affecting the growth of the steady state per capita Regional Gross Domestic Product. The simulation done using the model developed showed that by controling the previously mentioned economic growth determinant factors, it was possible to induce faster convergence process tendency per annum rate to $1,56 \%-4,75 \%$, with reduced half-life time to 10,24-31,76 years. Therefore, a faster regional economic convergence would require more physical and human capital to be distributed evenly among the main island regions, while constraining population growth and capital depreciation. Considering that each main island region owns a relatively abundant marine resource, therefore the convergence rate inducing policy should be implemented by pushing the role of marine sectors, while strengthening the sectoral and spatial connectivity among regions in Indonesia.

\section{Keywords: convergence, growth of regional GDP, main's island region, panel data}

\section{PENDAHULUAN}

Indonesia merupakan salah satu negara kepulauan (archipelagic state) terbesar di dunia memiliki wilayah kepulauan Indonesia tergolong sangat luas, yaitu dengan luas daratan sebesar 1,92 juta $\mathrm{km}^{2}$ dan luas perairan nusantara dan laut teritorial sebesar 3,1 juta $\mathrm{km}^{2}$ serta luas perairan ZEEI (Zona Ekonomi Ekslusif Indonesia) sebesar 2,7 juta $\mathrm{km}^{2}$, dan memiliki garis pantai sepanjang $81.000 \mathrm{~km}$. Di samping itu, Indonesia sebagai negara kepulauan (archipelagic state) memiliki sebanyak 19.508 pulau, dengan enam pulau utama yang berbasis pesisir di Indonesia, yaitu Pulau Sumatera, Pulau Kalimantan dan Pulau Jawa, Pulau Bali - Nusa Tenggara, Pulau Sulawesi, dan Pulau Irian Jaya (sekarang Papua) - Kepulauan Maluku (Adisasmita, 2008),

Sebagai negara kepulauan, perbedaan karakteristik wilayah merupakan sebuah konsekuensi yang tidak dapat dihindari oleh Indonesia. Karakteristik wilayah mempunyai pengaruh yang kuat terhadap terciptanya pola pembangunan ekonomi (Sirojuzilam, 2009). Dalam perspektif ekonomi spasial, wajar bila pola pembangunan ekonomi wilayah di Indonesia tidak seragam, dan melahirkan wilayah yang mampu tumbuh cepat sekaligus memunculkan pula wilayah yang relatif tertinggal atau tumbuh lebih lambat dari wilayah lainnya. Kemampuan untuk tumbuh yang berbeda ini akan mengakibatkan ketimpangan ekonomi wilayah di Indonesia. Kondisi ini umumnya didorong perbedaan sumberdaya yang dimiliki oleh masing-masing wilayah dengan kecenderungan wilayah yang memiliki sumberdaya yang memadai akan mencapai pertumbuhan ekonomi tinggi (Kuncoro, 2004).

Oleh karena itu, dapat dipahami bahwa ketimpangan ekonomi antar wilayah pulau utama di
Indonesia merupakan sesuatu yang secara alamiah akan terjadi. Mencermati fenomena ketimpangan tersebut sama halnya dengan mengamati proses konvergensi yang terjadi pada wilayah-wilayah pulau utama di Indonesia, karena konvergensi diinterpretasikan sebagai kecenderungan semakin mengecilnya ketimpangan (disparitas) ekonomi antar negara wilayah dalam suatu kurun waktu tertentu (Sala-i-Martin, 1996). Untuk itu, tulisan ini bertujuan menganalisis tendensi proses konvergensi ekonomi wilayah pulau utama yang berbasis pesisir di Indonesia termasuk menduga penentu pertumbuhan ekonomi dan kontribusinya terhadap kecepatan konvergensi dan half-life yang dibutuhkan untuk mengurangi setengah ketimpangan menuju kondisi steady-state wilayah.

\section{METODOLOGI PENELITIAN}

\section{Landasan Teroitis: Konsep, Hipotesis dan Ukuran Konvergensi}

\section{Konsep Konvergensi}

Barro dan Sala-i-Martin (1996) menjelaskan konsep konvergensi dalam ekonomi adalah suatu tingkat pendapatan per kapita yang lebih rendah tetapi bisa mencapai tingkat pertumbuhan yang lebih cepat pada masa selanjutnya. Perilaku ini sering disebut dengan konvergensi (convergence) yang ditunjukkan dengan tingkat dispersi (penyebaran) pendapatan per kapita antar kelompok ekonomi yang cenderung menurun sepanjang waktu. Selain pendapatan per kapita periode awal, terdapat sejumlah peubah struktural yang mempengaruhi konvergensi. Peubah struktural tersebut adalah sektor pertanian, pertambangan, konstruksi, manufaktur, perdagangan, keuangan dan real estate, transportasi, dan jasa. Peubah-peubah struktural tersebut akan menjadi indikator seberapa 
cepat pendepatan per kapita suatu negara atau wilayah akan tumbuh jika masing-masing sektor tersebut tumbuh secara agregat.

Secara teoritis terdapat dua alasan utama yang menjelaskan terjadinya konvergensi, yaitu (Mankiw, 2003):

1. Perbedaan tingkat output per kapita antar wilayah atau negara terjadi karena perbedaan rasio modal dengan tenaga kerja antar wilayah atau negara. Wilayah atau negara lebih makmur (kaya) memiliki rasio modal per tenaga kerja yang lebih besar, sehingga return on capital-nya rendah. Wilayah atau negara yang kurang makmur (miskin) memiliki rasio yang lebih kecil dan return on capital-nya lebih tinggi. Hal itu mendorong terjadinya aliran modal dari wilayah atau negara yang makmur (kaya) ke wilayah atau negara yang kurang makmur (miskin).

2. Perbedaan output per kapita terjadi karena perbedaan teknologi. Aliran teknologi terjadi dari wilayah atau negara berteknologi tinggi ke wilayah atau negara berteknologi rendah. Aliran tersebut dapat melalui beberapa cara, yaitu seperti: transfer teknologi, investasi langsung, dan pembelian macam-macam produksi oleh wilayah atau negara yang terbelakang.

Transisi dinamis model dengan pertumbuhan penduduk menunjukkan bahwa ketika perekonomian masih cukup jauh dari steady state, $k^{*}$, semakin besar penurunan aktual rasio kapital per tenaga kerja di bawah $\mathrm{k}^{*}$ maka semakin besar gap antara kurva y dan sy, sehingga tingkat pertumbuhan kapital per pekerja semakin tinggi. Dengan kata lain, bila perekonomian tidak berada pada jalur pertumbuhan keseimbangan, atau $K / Y$ di bawah tingkat pertumbuhan keseimbangan, maka kapital per pekerja akan meningkat dan output juga akan meningkat. Sebaliknya apabila K/Y di atas tingkat pertumbuhan keseimbangan, maka kapital per pekerja akan turun dan output juga akan turun. Proses tersebut dinamakan konvergensi menuju ke arah pertumbuhan keseimbangan. Selanjutnya karena rasio kapital terhadap output konvergen menuju keseimbangannya, maka tingkat pertumbuhan output per pekerja juga konvergen pada jalur pertumbuhan keseimbangan (Amstrong dan Taylor, 2001).
Lebih lanjut Amstrong dan Taylor (2001) menjelaskan bahwa dalam jangka panjuang, jika perekonomian saat ini telah berada pada jalur pertumbuhan keseimbangan, maka ke depan perekonomian tetap berada pada jalur keseimbangan, kecuali beberapa parameter s, n, g, $\delta$ dan a berubah. Tetapi jika pada saat ini perekonomian belum berada pada jalur pertumbuhan keseimbangan, maka pada masa mendatang kondisi ekonomi akan menuju pada jalur pertumbuhan keseimbangan. Kemudian seberapakah kecepatan perekonomian menuju ke jalur pertumbuhan ke seimbangan, hal ini dapat dijelaskan sebagai berikut. Misalkan kita memiliki fungsi produksi:

$$
Y=K_{t}^{\alpha}\left(A_{t} L_{t}\right)^{1-\alpha}
$$

Selanjutnya untuk menderivasi tingkat pertumbuhan output per pekerja, Persamaan (1) dapat dinyatakan dalam satuan output per pekerja dan kapital per pekerja dan diderivasi terhadap waktu, sehingga diperoleh persamaan sebagai berikut:

$$
\frac{\partial y_{t}}{\partial t}=(1-\alpha) g+\alpha \frac{\partial k_{t}}{\partial t}
$$

dimana $y_{t}=Y_{t} / L_{t}$ dan $k_{t}=K_{t} / L_{t}$. Persamaan ini memungkinkan kita melakukan pendugaan atau estimasi secara ekonometrik untuk menghitung tingkat diminishing return to capital, a dan tingkat pertumbuhan teknologi, $g$ dengan memanfaatkan data output, input tenaga kerja dan stok kapital.

Kemudian Amstrong dan Taylor (2001) menjelaskan bahwa Model Solow-Swan membuat asumsi bahwa dimungkinkan mengganti data stok kapital pada Persamaan (2) dengan data investasi diukur dari persamaan akumulasi kapital:

$$
\frac{\partial K}{\partial t}=s Y-\delta K
$$

dimana $\delta$ adalah tingkat depresiasi dan diasumsikan $s$ adalah bagian tabungan yang diinvestasikan. Kemudian kita mendefinisikan semua peubah dalam unit efisiensi pekerja, yaitr: $\tilde{y}=Y / A L$ dan $\widetilde{k}=K / A L$, sehingga Persamaan (3) dapat dituliskan:

$$
\widetilde{y}=\widetilde{k}_{t}^{\alpha}
$$

dengan kendala anggatan dalam perekonomian adalah: 
dengan kendala anggatan dalam perekonomian adalah:

$$
\begin{aligned}
& \frac{\partial \tilde{k}_{t}}{\partial t}=s \tilde{y}_{t}-(g+n+\delta) \tilde{k}_{t} \text { atau } \\
& \frac{\partial \tilde{k}_{t}}{\partial t}=s \tilde{k}_{t}^{*}-(g+n+\delta) \tilde{k}_{t}
\end{aligned}
$$

Dalam kondisi steady state, tingkat pertumbuhan kapital $(\mathrm{k})$ sama dengan 0 , sehingga dengan memanipulasi matematika, kita memperoleh stok kapital per pekrja efektif pada kondisi steady state sebesar:

$\tilde{k}^{*}=\left[\frac{s}{g+n+\delta}\right]^{\frac{1}{1-\alpha}}$

dan output per pekerja efektif adalah:

$\tilde{y}^{*}=\left[\frac{s}{g+n+\delta}\right]^{\frac{\alpha}{1-\alpha}}$

Adapun besarnya output per pekerja pada kondisi steady state:

$y^{*}=\left[\frac{s}{g+n+\delta}\right]^{\frac{1}{1-\alpha}} A_{t}$

Persamaan (3) dapat disubstitusikan ke Persamaan (2) untuk menderivasi tingkat pertumbuhan output per pekerja efektif sebagai berikut:

$$
\frac{\partial \log \tilde{y}_{t}}{\partial t}=\alpha\left[s \dddot{y}^{\frac{\alpha-1}{\alpha}}-(g+n+\delta)\right]
$$

Mankiw, Romer dan Weil (MRW) melakukan linierisasi persamaan di atas dan kemudian melakukan aproksimasi linier di sekitar steady state sehingga diperoleh bentuk aproksimasi sebagai berikut (Amstrong dan Taylor, 2001):

$\frac{\partial \log \tilde{y}_{t}}{\partial t} \cong(g+n+\delta)(\alpha-1)[\log \dddot{y}-\log \dddot{y} *]$

Persamaan (9) menyatakan bahwa tingkat pertumbuhan output per pekerja efektif adalah aproksimasi proporsional terhadap deviasi outputper pekerja efektif dari tingkat steady state $\mathrm{y}^{*}$. Namun dalam perhitungan satuan unit per pekerja efektif tidak dapat diamati, maka dilakukan transformasi ke dalam output per pekerja dan dapat dinyatakan dalam periode waktu yang diskrit. Langkah ini menghantar MRW melakukan aproksimasi pertumbuhan output per pekerja terhadap periode $\tau$, sehingga diperoleh Persamaan (10), sebagai berikut (Amstrong dan Taylor, 2001):

$$
\begin{gathered}
\log y_{t}-\log y_{t-1} \cong g \tau+\left(1-e^{-\chi \tau}\right) \\
\log A_{t-1}-\left(1-e^{-\chi \tau}\right) \log y_{t-1} \\
+\left(1-e^{-\chi \tau}\right) l\left(\frac{\alpha}{1-\alpha}\right)[\log s-\log (n+g+\delta)] . .
\end{gathered}
$$

dimana $\lambda=(n+g+\delta)(1-\alpha)$ adalah kecepatan konvergensi yang dihasilkan oleh akumulasi faktor input, yang merupakan dasar perhitungan konvergensi neoklasik. Selanjutnya Persamaan (10) oleh banyak peneliti konvergensi pendapatan dituliskan sebagai:

$\log \left(\frac{y_{t}}{y_{t-1}}\right)=\alpha-\beta \log y_{t-1}+\gamma X_{t-1}+\varepsilon_{t-1}$.

dimana, dan $\beta=\left(1-e^{-\chi}\right)$ serta $\mathrm{X}_{\mathrm{t}}$ adalah peubah-peubah penentu steady state, seperti $\mathrm{s}, \delta$ dan $\mathrm{n}$. Adapun sisi sebelah kiri persamaan menyatakan pertumbuhan pendapatan per kapita dalam interval waktu $\tau$ tahun.

Di samping kecepatan konvergensi neoklasik yang telah dijelaskan di atas, Dowrick dan Rogers (2002) juga mengembangkan kecepatan konvergensi yang menggambarkan tingkat transfer teknologi yang dapat dihitung dari nilai koefisien pendapatan per kapita awal dari Persamaan (11) yang dikaitkan dengan Persamaan (10) sebagai berikut:

$$
-\beta=\left(1-e^{-\chi x}\right) \text { atau } e^{-\chi}=1+\beta
$$

sehingga diperoleh kecepatan konvergensi:

$$
\lambda=-\frac{\log (1+\beta)}{\tau}
$$

\section{Hipotesis Konvergensi}

Mankiw (2003) menjelaskan bahwa model neoklasik memprediksi bahwa negara-negara akan 
tumbuh pada tingkat yang sama, dan perekonomian menunjukkan kondisi PDB per kapita yang berbeda ketika dalam proses menuju steady state. Model neoklasik memprediksi bahwa negara atau daerah yang memulai pembangunan dengan PDB per kapita yang lebih rendah seharusnya bisa tumbuh lebih cepat dibandingkan negara atau daerah yang memulai pembangunannya dengan tingkat PDB per kapita yang tinggi. Ide ini disebut hipotesis konvergensi (Convergence Hypothesis). Kita bisa mengontrol faktor-faktor yang menentukan konvergensi seperti tabungan, pertambahan penduduk, lamanya sekolah, stabilitas politik dan tipe pemerintahan (type of government). Kita sebaliknya melihat perkembangan negara yang memulai pembangunannya dengan stock of capital yang tinggi. Jepang, Jerman dan Italia (tipe negara yang tumbuh cepat) dari pada Amerika Serikat pascaperang dunia II karena mereka sedang mengejar ketertinggalanya melalui peran modal. Ide ini dinamakan hipotesis rekonstruksi (reconstruction hypotheisis).

Negara-negara miskin di dunia memiliki pendapatan per kapita kurang dari satu per sepuluh pendapatan rata-rata negara kaya. Perbedaan pendapatan ini terlihat dalam hampir ukuran kualitas hidup, mulai dari banyaknya televisi dan telepon per keluarga sampai tingkat konsumsi dan harapan hidup. Banyak penelitian dilakukan untuk menjawab pertaanyaan apakah ekonomi saling mendukung satu sama lain sepanjang waktu. Secara khusus, apakah perekonomian yang dinilai dari bawah (miskin) lebih cepat tumbuh dibandingkan dengan perekonomian yang lebih kaya?. Jika ya maka perekonomian dunia yang miskin akan dapat mengejar dunia yang sudah maju (kaya). Cara mengejar ini disebut konvergensi (convergence). Jika teknik statistik digunakan untuk mengendalikan beberapa determinan kondisi, seperti tingkat tabungan, tingkat pertumbuhan penduduk, dan tingkat pendidikan, maka data menunjukkan konvergensi pada tingkat $2 \%$ per tahun. Dengan kata lain, perekonomian dunia memperagakan konvergensi bersyarat (conditional convergence) (Mankiw, 2003).

Sebagaimana dijelaskan oleh Wibisono (2004) bahwa dalam literatur teori pertumbuhan ekonomi terdapat dua pandangan utama tentang proses konvergensi. Pada satu perspektif, --seperti Barro (1994), Barro and Sala-i-Martin (1991, 1995), Mankiw, Romer and Weil (1992), Islam (1995)-- konvergensi merujuk kepada konvergensi neoklasik; spesisifikasi pada model pertumbuhan
Solow-Swan (lihat misalnya Sala-i-Martin, 1996). Hipotesis utama dari model ini adalah diminishing returns to capital yang akan menyebabkan tingkat pertumbuhan suatu perekonomian melompat seiring dengan semakin dekatnya jarak perekonomian ke tingkat modal per tenaga kerja steady state. Selanjutnya spesifikasi Mankiw, Romer and Weil (1992) melineraisasi model Solow-Swan; memperkenalkan tingkat pendapatan per kapita awal sebagai ukuran jarak terhadap steady state. Spesisifkasi Mankiw, Romer and Weil (MRW) ini kemudian banyak diadopsi oleh studi-studi sejenis dan telah menjadi "industry standard" untuk bidangnya.

Satu aspek terpenting dari spesifikasi empiris MRW tersebut adalah asumsi bahwa semua perekonomian menerapkan teknologi baru pada tingkat yang sama. Asumsi tingkat pertumbuhan teknologi yang sama berimplikasi bahwa seluruh variasi dalam tingkat pertumbuhan antar negara harus bisa dijelaskan oleh variasi jarak perekonomian dari steady state dan oleh tingkat dimishing returns to capital. Dengan kata lain, model neoklasik memberi penekanan yang sangat besar pada akumulasi faktor (terutama modal) dalam menjelaskan pertumbuhan ekonomi (Wibisono, 2004).

Hal yang menjadi ironi bahwa kebangkitan penelitian pertumbuhan dalam dekade terakhir justru menunjukkan kekuatan dari model neoklasik 1950-an. Hal ini membawa ketidakpastian yang besar bagi banyak peneliti. Romer dalam Wibisono (2004) menggambarkan ketidakpuasan ini dengan tepat:

We could produce statistical evidence that all growth came from capital accumulation, with no room for anything called technological change. But we could not believe it.

Kesadaran untuk memberi perhatian yang lebih besar pada teknologi sebagai pendorong utama konvergensi sebenarnya telah cukup lama dimulai, antara lain oleh Baumol (1986), Dowrick dan Rogers (2002), Bernard and Jones (1996), dan Bond et al. (2001). Perspektif kedua ini mempertanyakan kepercayaan bahwa konvergensi neoklasik dengan dominasi peran akumulasi modal dalam menentukan tingkat pendapatan dan tingkat pertumbuhan relatif. Mereka berargumen bahwa perbedaan dalam teknologi antar negara bisa memiliki implikasi yang besar dalam konvergensi. Seperti yang diargumentasikan oleh New Growth 
Theory, teknologi akan mencegah diminishing returns to capital dan membuat perbedaan dalam pendapatan akan berlangsung terus menerus. Oleh karena itu, pertanyaan dari Bernard and Jones (1996) dalam Wibisono (2004) menjadi sangat relevan untuk penelitian tentang pertumbuhan ke depan:

Why do countries have different levels of technology? How do technologies change over time? ... How much of the convergence that we observe is due to convergence in technology versus convergence in capital-labour ratios?

Memasuki abad ke-21, mucul gelombang ketiga dari penelitian pertumbuhan dengan model konvergensi yang membedakan antara konvergensi yang dihasilkan dari akumulasi modal dan konvergensi yang dihasilkan dari transfer teknologi, seperti Dowrick and Rogers (2002).

\section{Ukuran Konvergensi}

Pertanyaan tentang konvergensi yang berpusat pada apakah perekonomianperekonomian dengan tingkat output awal yang berbeda ke standar hidup yang sama (konvergensi absolut). Teori neoklasik memprediksi konvergensi absolutbagi perekonomian dengan tingkat tabungan, pertambahan penduduk dan akses kepada teknologi yang sama, mereka akan mencapai pendapatan sama (steady state). Sementara konvergensi kondisional diprediksi bagi perekonomian dengan tingkat tabungan, pertambahan penduduk yang berbeda sehingga pendapatan steady state akan berbeda pula (Donbusch et al., 2004).

Sebagaimana disampaikan Wibisono (2004), studi empiris tentang konvergensi antar negara dan antar daerah umumnya terfokus pada dua ukuran utama konvergensi. Ukuran pertama, --seperti Barro (1994), Baumol (1986), Barro and Sala-iMartin (1991, 1995)-- memfokuskan perhatian pada dispersi antar perekonomian (cross-sectional dispersion). Dalam pandangan ini, konvergensi terjadi manakala dispersi --yang umumnya diukur oleh standar deviasi dari log PDB riil per kapita-antar negara atau daerah semakin menurun sepanjang waktu. Proses ini disebut $\sigma$-convergence. Ukuran kedua, pada satu perspektif, --seperti Baumol (1986), Barro (1994), dan Barro and Sala-i-Martin (1991;1995)-- konvergensi terjadi manakala perekonomian miskin cenderung tumbuh lebih cepat dibandingkan perekonomian kaya. Properti ini berhubungan dengan konsep $\beta$-convergence yang diperoleh dari analisis regresi antar perekonomian.

Dengan demikian, secara teoritis dikenal dua ukuran konvergensi yang sering digunakan oleh para peneliti konvergensi pendapatan wilayah, yaitu (Young et al., dalam Sufii, 2008):

1. Konvergensi Sigma $(\sigma)$, menggambarkan dispersi perndapatan per kapita makin mengecil dari waktu ke waktu. Kerangka konvergensi agregat ini konsisten dengan teori neoklasik yang menyatakan bahwa setiap wilayah (daerah) bergerak menuju (konvergen) satu level pertumbuhan ekonomi tertentu karena terjadi keseimbangan penguasaan faktorfaktor produksi antar wilayah (daerah). Konsep ini dapat diukur dengan ukuran penyebaran (dispersi) seperti standar deviasi atau coefficient of variation.

2. Konvergensi Beta ( $\beta)$, bertujuan untuk mengetahui hubungan antara pertumbuhan pendapatan per kapita dengan pendapatan per kapita pada periode awal. Bila hubungan tersebut adalah negatif, diartikan bahwa negara atau wilayah (daerah) yang memiliki pendapatan per kapita tinggi pada periode awal akan memiliki pertumbuhan pendapatan per kapita yang lebih rendah dibandingkan nagara atau wilayah (daerah) dengan pendapatan awal yang lebih rendah, sehingga pada suatu saat semua negara atau wilayah (daerah) akan memiliki tingkat pertumbuhan yang sama atau dikenal berada pada kondisi steady state.

Kedua perbedaan pengertian tersebut secara sederhana dapat dijelaskan bahwa konvergensi sigma ( $\sigma$-convergence) mempelajari perubahan distribusi pendapatan sepanjang waktu, sedangkan konvergensi beta ( $\beta$-convergence) mempelajari mobilitas pendapatan dalam distribusi yang sama. Meskipun secara konsep berbeda, namun konvergensi sigma ( $\sigma$-convergence) dan konvergensi beta ( $\beta$-convergence) saling berhubungan, dimana konvergensi beta ( $\beta$-convergence) cenderung akan menghasilkan konvergensi sigma ( $\sigma$-convergence). Namun proses ini kadang terhapus oleh gangguan baru yang cenderung meningkatkan dispersi ${ }^{1}$. Oleh karena itu, konvergensi beta ( $\beta$-convergence) 
merupakan syarat perlu (necessary condition), namun bukan syarat yang mencukupi (sufficient condition) bagi terjadinya konvergensi sigma ( $\sigma$-convergence). Walau tidak identik, tetapi secara empiris $\beta$-convergence akan terverifikasi manakala $\sigma$-convergence juga terverifikasi (De la Feunte, 2000).

Satu kelebihan utama dari $\beta$-convergence adalah bahwa apabila analisis bersifat dinamis. Bila pengamatan jangka pendek tidak mampu memberikan jawaban tentang dampak kebijakan publik, maka kita dapat melihat dampak tersebut dalam kecenderungan jangka panjang. Dengan analisis $\beta$-convergence, kita bisa mengetahui kecepatan konvergensi secara pasti. Jika konvergensi adalah cepat, maka fokus kita adalah pada perilaku steady-state; sebab kita tahu bahwa mayoritas perekonomian berada dekat pada posisi steady-state-nya. Namun jika tidak yang berarti bahwa mayoritas perekonomian berada jauh dari posisi steady-state-nya - maka fokus kita adalah pada pengalaman pertumbuhan yang dialami perekonomian dalam dinamika trasisional tersebut (de la Feunte dalam Sufii, 2008).

Dalam tataran empiris, koefisien konvergensi, $\beta$, mengindikasikan seberapa cepat output per tenaga kerja sebuah perekonomian, $\dot{y}$, mendekati nilai steady-state-nya, $\dot{y}^{*}$. Sebagai misal, jika $\beta=0,05$ per tahun, maka 5 persen dari kesenjangan antara $\dot{y}$ dan $\dot{y}^{*}$ akan ditutup dalam 1 tahun. Implikasinya adalah the half-life of convergence -yaitu waktu yang dibutuhkan untuk menutup setengah dari kesenjangan awal-- adalah sekitar 14 tahun $^{2}$. Dari sudut pandang teoritis, analisis $\beta$-convergence hanyalah analisis deskriptif dan sama sekali tidak berbicara tentang mekanisme dibalik bekerjanya konvergensi tersebut. Walau demikian, analisis ini adalah tes langsung terhadap hipotesis teori konvergensi neoklasik (dengan asumsinya tentang diminishing returns to capital) (Barro and Sala-i-Martin, 1995).

Selanjutnya Barro and Sala-i-Martin (1995) menjelaskan bahwa dalam konvergensi beta ( $\beta$-convergence) dikenal pula dua pengukuran, yaitu: (1) Konvergensi absolut (absolute convergence); dan (2) Konvergensi bersyarat (conditional convergence). Ukuran konvergensi absolut $\beta$ digunakan apabila hubungan antara pertumbuhan pendapatan per kapita dengan pendapatan awal (inital income) tanpa dikontrol oleh peubah-peubah lain. Karena peubah-peubah lain dianggap sama antar negara atau antar wilayah (antar daerah), maka ada kecenderungan ke depan terjadi penyamaan pendapatan per kapita dalam kelompok negara atau kelompok wilayah (daerah) tersebut. Kemudian ukuran konvergensi bersyarat/ kondisional $\beta$ digunakan apabila hubungan antara pertumbuhan pendapatan per kapita dengan per kapita awal yang dikontrol oleh peubah-peubah lain, misalnya tingkat tabungan, pertumbuhan penduduk, investasi dan lain-lain.

Studi-studi yang mencoba mengukur kecepatan konvergensi $\beta$ ini menghasilkan dua aliran utama dari regresi konvergensi (Barro and Sala-i-Martin, 1995). Pertama, adalah ide tentang club convergence. Regresi jenis ini bersandar pada hipotesis bahwa hanya negara-negara yang memiliki karakteristik struktural dan kondisi awal yang mirip saja yang akan konvergen satu sama lain. Negara-negara kaya OECD membentuk satu "convergence club", Negara-negara berkembang membentuk klub konvergensi lain, dan negaranegara miskin membentuk klub lainnya. Tidak terdapat kecenderungan untuk konvergen bagi klub-klub ini, karenanya disparitas antar klub-klub yang berbeda ini dapat terus berlangsung dalam jangka panjang, bahkan meningkat.

Kedua, formula dalam model konvergensi $\beta$ adalah apa yang disebut sebagai konvergensi kondisional; perekonomian akan konvergen bukan ke stady-state yang sama, melainkan ke steadystate masing-masing. Karakteristik struktural yang berbeda berimplikasi bahwa negara-negara akan memiliki tingkat steady-state pendapatan yang berbeda-beda pula. Metoda terpopuler disini adalah dengan menambahkan berbagai peubah bertipe struktural ke dalam "regresi pertumbuhan dasar". Sekali koefisien beta $(\beta)$ menunjukkan tanda negatif ketika peubah-peubah ini masuk

\footnotetext{
${ }^{1} \mathrm{Hal}$ ini terjadi karena konvergensi beta ( $\beta$-convergence) juga bergantung pada variasi error term dalam regeresi pertumbuhan. Walaupun dispersi jangka panjang akan turun seiring dengan koefisien beta, namun ia meningkat seiring dengan variasi dalam error term yang semakin membesar.

${ }^{2}$ Waktu $\mathrm{t}$ dimana $\log [\dot{y}(\mathrm{t})]$ adalah setengah perjalanan antara log $[\dot{y}(0)]$ dan log $\dot{y} *$ memenuhi kondisi $e^{-\beta t}=1 / 2$, maka the half-life adalah $\log (2) / \beta$. Jika $\beta=0,05$ per tahun maka the half-life adalah 14 tahun. Lihat Barro and Sala-i-Martin, 1995.
} 
sebagai peubah regressor, maka kita menyebut perekonomian yang kita teliti memperlihatkan konvergensi beta kondisional.

Beranjak dari studi-studi yang mengukur kecepatan konvergensi $\beta$ tersebut, kemudian timbul perhatian untuk melakukan analisis konvergensi antar daeah dalam suatu negara. Walaupun perbedaan dalam teknologi, preferensi dan institusi antar daerah adalah eksis, namun perbedaan ini relatif lebih baik dibandingkan dengan perbedaan antar negara. Perusahaan dan rumah tangga dalam satu negara cenderung memiliki akses terhadap teknologi yang sama dan memiliki selera dan kultur yang relatif sama. Lebih jauh lagi, daerah-daerah yang memiliki sistem dan institusi yang sama atau memiliki homogenitas relatif ini mendukung diterapkannya konvergensi absolut untuk studi antar daerah dalam satu negara (Barro and Sala-i-Martin, 1995).

\section{Jenis dan Sumber Data}

Analisis pendugaan proses dan penentu konvergensi ekonomi wilayah di Indonesia dilakukan dengan menggunakan rentang waktu dari data selama 25 tahun, yaitu sejak tahun 1985 hingga 2010. Jenis data yang digunakan adalah data sekunder dalam bentuk gabungan antara data runut waktu dan cross section dari provinsi-provinsi dalam wilayah pulau utama yang berbasis pesisir di Indonesia sebagai "unit analisis" yang dhitung berdasarkan agregasi data dari provinsi-provinsi yang dihimpun dari berbagai sumber. Adapun jenis dan sumber data tersebut secara rinci tersaji pada Tabel 1.

Tabel 1. Definisi Peubah dan Sumber Data yang digunakan dalam Analisis Konvergensi Ekonomi dan Pertumbuhan Ekonomi Wilayah Pulau Utama di Indonesia.

Table 1. Variables Defenition and Sourch of Data which Used in Analysis of Economic Convergence and Economic Growth of Main's Inlands Regions in Indonesia.

\begin{tabular}{|c|c|c|}
\hline Peubah/ Variables & Defenisi/ Defenition & Sumber data/ Source of Data \\
\hline $\begin{array}{l}\text { Pertumbuhan ekonomi/ } \\
\text { Economic growth } \\
\left(\left(\text { PDRBK }_{\mathrm{it}}-\mathrm{PDRBK}_{\mathrm{it}-1}\right) /(\right. \\
\left.\left.\text { PDRBK }_{\mathrm{it}-1}\right)\right)\end{array}$ & $\begin{array}{l}\text { Pertumbuhan PDRB per kapita tahunan } \\
\text { masing-masing wilayah pulau utama/ } \\
\text { Yearly of Growth of per capita regional } \\
\text { GDP every main inlands regions }\end{array}$ & $\begin{array}{l}\text { Publikasi PDRB menurut Lapangan } \\
\text { Usaha Provinsi-provinsi, BPS/ } \\
\text { Publication of region GDP based on } \\
\text { Provincials Frims, BPS }\end{array}$ \\
\hline 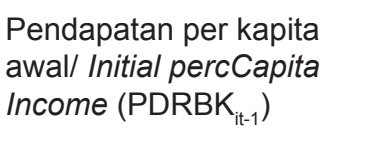 & $\begin{array}{l}\text { Pendapatan per kapita wilayah pulau } \\
\text { utama pada tahun awal (lag satu tahun)/ } \\
\text { Per capita income of main inlands } \\
\text { regions at initial year (lag one year) }\end{array}$ & $\begin{array}{l}\text { Publikasi PDRB menurut Lapangan } \\
\text { Usaha Provinsi-provinsi, BPS/ } \\
\text { Publication of region GDP based on } \\
\text { Provincials Frims, BPS }\end{array}$ \\
\hline $\begin{array}{l}\text { Tingkat investasi Fisik/ } \\
\text { Phisical investment level } \\
\left(\text { PMTDB }_{\mathrm{it}}\right)\end{array}$ & $\begin{array}{l}\text { Rasio Pembentukan Modal Tetap } \\
\text { Domestik Bruto terhadap PDRB masing- } \\
\text { masing wilayah pulau utama/ Ratio from } \\
\text { bruto domestic fixed capital on region } \\
\text { GDP every main inlands regions }\end{array}$ & $\begin{array}{l}\text { Publikasi PDRB menurut Penggunaan } \\
\text { Provinsi-provinsi, BPS/ Publication of } \\
\text { region GDP based on Provincials Frims, } \\
\text { BPS }\end{array}$ \\
\hline $\begin{array}{l}\text { Tingkat investasi manusia/ } \\
\text { Human investment capital } \\
\left(\mathrm{HUCAP}_{\text {it }}\right)\end{array}$ & $\begin{array}{l}\text { Rasio pekerja berpendidikan SLTA ke } \\
\text { atas terhadap total pekerja berusaia } 15 \\
\text { tahun ke atas di masing-masing wilayah } \\
\text { pulau utama/ Ratio from worker with } \\
\text { upward enrole senior education every } \\
\text { main inlands regions }\end{array}$ & $\begin{array}{l}\text { Publikasi sensus penduduk (SP), Survei } \\
\text { Penduduk Antar Sensus (SUPAS) dan } \\
\text { proyeksi penduduk berdasarkan SP, } \\
\text { BPS/ Publication of pupolation cencus } \\
\text { (SP), survey of pupulation between } \\
\text { Cencus (SUPAS) and projection of } \\
\text { population based on SP, BPS }\end{array}$ \\
\hline $\begin{array}{l}\text { Resultante (jumlah) dari } \\
\text { tingkat pertumbuhan } \\
\text { penduduk, tingkat } \\
\text { perkembangan teknologi } \\
\text { dan tingkat penyusutan } \\
\text { modal / Resultant from } \\
\text { population growth, } \\
\text { technological progress } \\
\text { level and capital } \\
\text { depretiation level } \\
\left((n+g+\delta)_{\text {it }}\right)\end{array}$ & $\begin{array}{l}\text { Penjumlahan dari tingkat pertumbuhan } \\
\text { tahunan penduduk ditambah } 0,05 \\
\text { (diasumsikan tingkat perkembangan } \\
\text { teknologi dan tingkat penyusutan modal } \\
\text { sebesar } 0,05 \text { )/ Resultante from yearly of } \\
\text { population growth added } 0.05 \text { (assumed } \\
\text { that technological progress level and } \\
\text { capital depretiation level by } 0.05 \text { ) } \\
\text { (Romer, 1996; Wibisono, 2004) }\end{array}$ & $\begin{array}{l}\text { Publikasi sensus penduduk (SP), Survei } \\
\text { Penduduk Antar Sensus (SUPAS) serta } \\
\text { proyeksi penduduk berdasarkan SP, } \\
\text { BPS/ Publication of pupolation cencus } \\
\text { (SP), survey of pupulation between } \\
\text { Cencus (SUPAS) and projection of } \\
\text { population based on SP, BPS }\end{array}$ \\
\hline
\end{tabular}




\section{Spesifikasi Model Analisis}

Model analisis yang digunakan dalam penelitian ini menggunakan spesifikasi yang merujuk pada model Mankiw, Romer and Weil/ MRW (1992) yang menurunkan peubah-peubah yang mempengaruhi steady-state secara langsung dari model Solow-Swan. Peubah-peubah ini adalah tingkat akumulasi modal fisik (investasi), tingkat akumulasi modal manusia, dan resultante dari jumlah tingkat pertumbuhan penduduk, tingkat perkembangan teknologi, dan tingkat depresiasi kapital. Secara sengaja, penelitian ini tidak memasukkan peubah-peubah lainnya dalam model pertumbuhan yang digunakan, tetapi konsisiten dengan peubah-peubah penjelas yang digunakan dalam model MRW. Hal ini dimaksudkan untuk menghindari ketidak-tepatan model yang membawa masalah bias spesifikasi, khususnya dalam menduga tendensi prose konvergensi. Dengan demikian, model analisis diduga dalam penelitian ini, pada pokoknya adalah sebagai berikut:

$$
\begin{aligned}
& \ln \left(\frac{P D R B_{i t}}{P D R B_{i t-1}}\right)=\beta_{0}+\beta_{1} \ln \left(\text { PDRB }_{i t-1}\right)+ \\
& \beta_{2} \ln \left(P M T D B_{i t}\right)+\beta_{3} \ln \left(H U C A P_{i t}\right) \\
& +\beta_{4}(n+g+d)_{i t}+u_{i t}
\end{aligned}
$$

dimana:

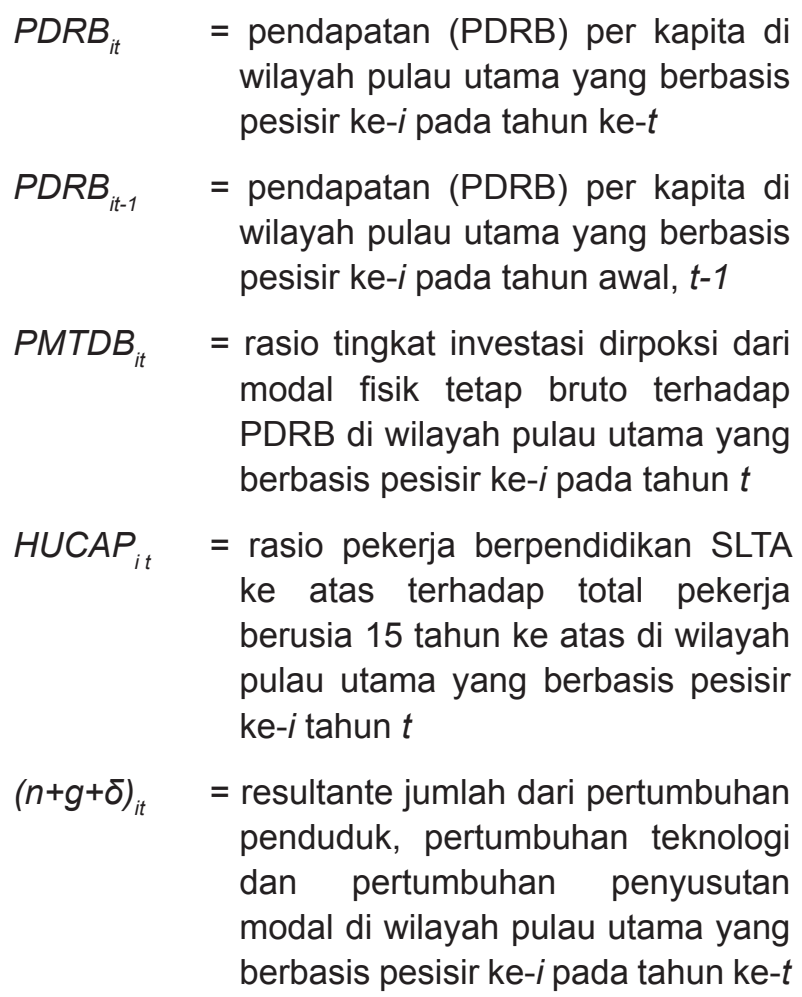

$u_{i t} \quad=$ gangguan (disturbances) pada komponen sisaan satu arah/ one way component model, yang didefenisikan sebagai: $\mu_{\mathrm{it}}+\eta_{\mathrm{i}}$

$\mu_{\mathrm{it}} \quad=$ Efek spesifik sebuah periode waktu, dengan $\mu_{i t} \approx N\left(0, \sigma^{2}\right)$ sebagai komponen error yang berkorelasi dengan waktu dan wilayah yang berbeda $\left(E\left(\bigcup_{i t} U_{j t}\right)=0\right.$, jika $i \neq j$ atau $\mathrm{t} \neq \mathrm{s}$ )

$\eta_{\mathrm{i}} \quad=$ Peubah efek individual atau efek yang tidak dapat diamati yang merepresentasikan faktor-faktor spesifik wilayah yang tidak diamati (unobserved region)

\section{Metode Pendugaan Model Analisis}

Dalam penelitian ini pendugaan Persamaan (13) dilakukan dengan menggunakan pendekatan ekonometrika data panel, dan dengan mempertimbangkan asumsi yang digunakan mengenai intersep, slope, dan sisaan $u_{i t}$, sehingga berdasarkan variasi-variasi asumsi yang dibentuk akan diuji tiga model regresi data panel tersebut, yaitu: (1) Metode Common Effect Model (CEM) atau dikenal juga dengan sebutan Metode Pooled OLS (PLS); (2) Metode Fixed Effect Model (FEM); dan (3) Metode Random Effect (REM) (Widarjono, 2007; Juanda dan Junaidi, 2011). Selanjutnya, berdasarkan hasil pendugaan tersebut, dilakukan pengujian tendensi proses konvergensi dan kecepatan konvergensi serta half-life-nya, yaitu sebagai berikut:

a. Tendensi proses konvergensi ekonomi wilayah pulau utama yang berbasis pesisir di Indonesia dapat diketahui dari tanda (sign) yang dimiliki koefisien regresi peubah pendapatan per kapita awal $\left(\beta_{1}\right)$ dari hasil pendugaan spesifikasi persamaan yang dianalisis. Menurut Dowrick dan Rogers (2002), jika tanda koefisien regresi peubah pendapatan per kapita awal $\left(\beta_{1}\right)$ menunjukkan arah (sign) yang negatif dan signifikan, disimpulkan bahwa "telah" terjadi tendensi proses konvergensi ekonomi wilayah pulau utama yang berbasis pesisir di Indonesia.

b. Ukuran kecepatan konvergensi ekonomi wilayah pulau utama yang berbasis pesisir di Indonesia terimplikasi dengan pengejaran atau transfer teknologi $(\lambda)$ 
dihitung berdasarkan nilai koefisien regresi peubah pendapatan per kapita awal $\left(\beta_{1}\right)$ dari hasil pendugaan, yaitu: $\lambda=-\log \left(1+\beta_{1}\right)$.

c. Ukuran half-life yang menunjukkan waktu yang dibutuhkan untuk mencapai kondisi steady state dari perekonomian wilayah atau waktu yang diperlukan untuk menurunkan setengah dari ketimpangan ekonomi wilayah menuju kondisi steady state dari perekonomian wilayah, dihitung sebagai: $-\log (0,5) / \lambda$ atau sama dengan $\log (2) / \lambda$

Setelah diperoleh hasil pendugaan terhadap model Persamaan (1) yang diikuti pendugaan faktor-faktor penentu pertumbuhan ekonomi wilayah, kemudian dilanjutkan dengan uji untuk mengetahui kontribusi faktor-faktor penentu pertumbuhan yang mempengaruhi kecapatan konvergensi ekonomi wilayah pulau utama yang berbasis pesisir Indonesia, 1985-2010. Uji ini dilakukan dengan menggunakan Uji Wald yang merupakan uji perbedaan yang banyak digunakan untuk menguji berbagai restriksi dalam persamaan regresi (Long, 1997; Green, 2000). Uji Wald ini dilakukan untuk menguji uji apakah koefisien regresi peubah-peubah penentu pertumbuhan ekonomi tersebut adalah nyata terhadap kecepatan konvergensi ekonomi antar wilayah pulau utama yang berbasis pesisir di Indonesia.

\section{HASIL DAN PEMBAHASAN}

\section{Pendugaan Tendensi Proses Konvergensi Ekonomi Wilayah}

Salah satu prediksi dari teori pertumbuhan Solow adalah terjadinya konvergensi pendapatan per kapita antar negara atau wilayah yang berkaitan dengan kondisi ketimpangannya (Salai-Martin, 1996). Pendugaan konvergensi dalam penelitian ini dilakukan untuk melihat apakah perbedaan pertumbuhan pendapatan per kapita wilayah pulau utama yang berbasis pesisir di Indonesia menunjukkan tendensi yang konvergen atau divergen. Menurut Barro (2000), tingkat pertumbuhan pendapatan per kapita suatu negara atau wilayah cenderung berhubungan terbalik dengan tingkat pendapatan awalnya, sehingga indikasi konvergensi ini muncul jika diperoleh hubungan negatif antara pertumbuhan pendapatan per kapita dengan pendapatan per kapita awal. Oleh karena itu, tendensi proses konvergensi ekonomi wilayah pulau utama yang berbasis pesisir di
Indonesia ini dapat ditunjukkan berdasarkan tanda (sign) negatif pada koefisien pendapatan awalnya, dan bila sebaliknya menunjukkan pendapatan wilayah bersifat persisten atau terjadi divergensi (Dowrick dan Rogers, 2002).

Tabel 2 memperlihatkan bahwa berdasarkan hasil pendugaan model common effect (CEM), model fixed effect (FEM), dan model random effect (REM) disimpulkan telah terjadi proses tendensi proses konvergensi absolut ekonomi (pendapatan per kapita) antar wilayah pulau utama yang berbasis pesisir di Indonesia untuk periode 1985-2010. Hal ini ditunjukkan oleh nilai koefisien parameter pendapatan per kapita awal $\left(\beta_{1}\right)$ yang memiliki arah (sign) negatif, atau memiliki nilai lebih kecil dari satu. Hasil pendugaan ini terlihat memuaskan baik pada pengujian individual maupun keseluruhan yang nyata pada taraf $\alpha=0,01$, dengan koefisien paramater peubah pendapatan per kapita awal $\left(P D R B K_{t-1}\right)$ yang menunjukkan tanda yang sesuai harapan atau konsisten dengan teori dan dengan kecepatan konvergensi absolut berkisar antara 1,46 hingga 3,75\% per tahun serta half-life antara selama $18,50-47,51$ tahun.

Dibandingkan dengan penelitian lainnya di Indonesia, hasil ini sesuai dengan penelitian Vidyattama (2006) yang menemukan bahwa telah terjadi proses konvergensi absolut dalam pendapatan per kapita antar provinsi selama 1975-2002 dengan besaran koefisien perndapatan per kapita awal sebesar $-1,5 \%$ atau kecepatan konvergensi sebesar 1,51\% per tahun untuk CEM. Hasil ini juga mendekati sama dengan temuan penelitian Wibisono (2004) yang mendapatkan konvergensi absolut dengan kecepatan konvergensi sebesar 1,3\% per tahun untuk CEM dan sebesar $1,49 \%$ per tahun untuk FEM. Hal yang sama juga berlaku bila dibandingkan dengan penelitian di Mexico selama 1970-2003 dengan kecepatan konvergensiyang diindikasikan oleh besara koefisien $\beta_{1}$ sebesar $-0,2 \%$ untuk CEM, dan di Argentina sebesar $-0,5 \%$ untuk FEM, dan di Brazil sebesar $-0,6 \%$ untuk REM (Serra, 2006). Sementara hasil penelitian ini lebih rendah dibandingkan penelitian di negara berkembang lainnya, seperti di Philipina selama 1988-1997 dengan kecepatan konvergensi sebesar 10,7\% per tahun (Balisacan dan Fuwa, 2003). Namun berbeda halnya bila dibandingkan penelitian di luar negeri lainnya, yang ditemukan adanya kesesuaian. Kecepatan konvergensi yang ditunjukkan besaran koefisien konvergensi yang ditemukan di China selama 1978-1993 
Tabel 2. Hasil Pendugaan Tendensi Proses Konvergensi Absolut Ekonomi Antar Wilayah Pulau Utama di Indonesia, 1985-2010.

Table 2. Output of Estimation on Tendention of Absolute Convergence Process among Main's Inland Regions in Indonesia, 1985-2010.

\begin{tabular}{|c|c|c|c|c|c|c|}
\hline \multirow[b]{2}{*}{ Peubah/Variables } & \multicolumn{2}{|c|}{$\begin{array}{c}\text { Common Effect } \\
\text { Model }\end{array}$} & \multicolumn{2}{|c|}{$\begin{array}{l}\text { Fixed Effect } \\
\text { Model }\end{array}$} & \multicolumn{2}{|c|}{$\begin{array}{c}\text { Random Effect } \\
\text { Model }\end{array}$} \\
\hline & $\begin{array}{l}\text { Koefisien/ } \\
\text { Coefficent }\end{array}$ & $\begin{array}{l}\text { Nilai } \\
\text { Prob.l } \\
\text { Value of } \\
\text { Prob. }\end{array}$ & $\begin{array}{l}\text { Koefisien/ } \\
\text { Coefficent }\end{array}$ & $\begin{array}{l}\text { Nilai } \\
\text { Prob. I } \\
\text { Value of } \\
\text { Prob. }\end{array}$ & $\begin{array}{l}\text { Koefisien/ } \\
\text { Coefficent }\end{array}$ & $\begin{array}{l}\text { Nilai } \\
\text { Prob. I } \\
\text { Value of } \\
\text { Prob. }\end{array}$ \\
\hline - Konstanta/ Constant & 0.0880 & 0,0000 & 0.1527 & 0.0000 & 0.0825 & 0.0000 \\
\hline $\begin{array}{l}\text { - Pendapatan per Kapita Awal/ } \\
\text { Initial per Capita Income (Ln } \\
\left.\text { PDRBK } K_{i t-1}\right)\end{array}$ & -0.0165 & 0,0000 & -0.0368 & 0.0000 & -0.0145 & 0.0077 \\
\hline $\mathrm{R}^{2}$ & 0.1522 & & 0.3034 & & 0.0473 & \\
\hline $\mathrm{R}^{2}$-adjust & 0.1465 & & 0.2742 & & 0.0409 & \\
\hline F-statistic & 26.5704 & & 10.3821 & & 7.3480 & \\
\hline Prob(F-stat.) & 0.0000 & & 0.0000 & & 0.0075 & \\
\hline DW & 1.3233 & & 1.4542 & & 1.7411 & \\
\hline $\begin{array}{l}\text { Kecepatan Konvergensi/ Speed } \\
\text { of Convergence, } \lambda(\%)\end{array}$ & 1.66 & & 3.75 & & 1.46 & \\
\hline Half-life (\%) & 41.77 & & 18.50 & & 47.51 & \\
\hline Uji Chow/ Chow Test & \multicolumn{6}{|c|}{$\begin{array}{l}\text { Ho ditolak pada taraf } \alpha=0.05 / \mathrm{Ho} \\
\text { rejected at level } \alpha=0,05\end{array}$} \\
\hline Uji Housemen/ Housemen Test & & & \multicolumn{4}{|c|}{$\begin{array}{l}\text { Ho ditolak pada taraf } \alpha=0,05 / \mathrm{Ho} \\
\text { rejected at level } \alpha=0,05\end{array}$} \\
\hline
\end{tabular}

Sumber: Hasil pengolahan data/ Source: Output from data processing (2013)

sebesar 1,7\% (Jian et al., 1996) atau sebesar 2\% per tahun selama 1978-1989 (Gundlach, 1997) untuk CEM. Demikian pula dengan hasil penelitian Sala-i-Martin di Kanada dan Spanyol masingmasing menemukan kecepatan konvergensi sebesar $-2,4 \%$ dan $-2,3 \%$ per tahun untuk FEM, dan di Jerman sebesar $-1,4 \%$ per tahun untuk REM.
Pengujian selanjutnya adalah terhadap tendensi proses konvergensi kondisional (bersyarat) segaimana terlihat pada Tabel 3 yang diduga menggunakan CEM, FEM dan REM ternyata memberikan tanda (sign) koefisien parameter peubah pendapatan per kapita awal yang negatif dan nyata pada taraf $\alpha=0,001$ (Tabel 3).

Tabel 3. Hasil Pendugaan Proses Konvergensi Kondisional Antar Wilayah Pulau Utama di Indonesia, 1985-2010.

Table 3. Output of Estimation on Tendention of Conditional Convergence Process among Main's Inland Regions in Indonesia, 1985-2010.

\begin{tabular}{|c|c|c|c|c|c|c|}
\hline \multirow[b]{2}{*}{ Peubah/ Variables } & \multicolumn{2}{|c|}{$\begin{array}{c}\text { Common Effect } \\
\text { Model }\end{array}$} & \multicolumn{2}{|c|}{$\begin{array}{c}\text { Fixed Effect } \\
\text { Model }\end{array}$} & \multicolumn{2}{|c|}{$\begin{array}{c}\text { Random Effect } \\
\text { Model }\end{array}$} \\
\hline & $\begin{array}{l}\text { Koefisien/ } \\
\text { Coefficent }\end{array}$ & $\begin{array}{c}\text { Nilai } \\
\text { Prob. I } \\
\text { Value of } \\
\text { Prob. }\end{array}$ & $\begin{array}{l}\text { Koefisien/ } \\
\text { Coefficent }\end{array}$ & $\begin{array}{c}\text { Nilai Prob. } \\
\text { I Value of } \\
\text { Prob. }\end{array}$ & $\begin{array}{l}\text { Koefisien/ } \\
\text { Coefficent }\end{array}$ & $\begin{array}{c}\text { Nilai } \\
\text { Prob. I } \\
\text { Value of } \\
\text { Prob. }\end{array}$ \\
\hline - Konstanta/ Constant & 0.1539 & 0.0000 & 0.3215 & 0.0000 & 0.2044 & 0.0000 \\
\hline $\begin{array}{l}\text { - Investasi Fisik/ Physical } \\
\left.\text { Investment (Ln PMTDB }{ }_{i t}\right)\end{array}$ & 0.0353 & 0.0000 & 0.0250 & 0.0053 & 0.0307 & 0.0024 \\
\hline $\begin{array}{l}\text { - Investasi Modal Manusia/ } \\
\text { Human Capital Investment } \\
\left(\text { Ln HUCAP }{ }_{i t}\right)\end{array}$ & -0.0004 & 0.9486 & 0.0341 & 0.0078 & 0.0223 & 0.0056 \\
\hline
\end{tabular}


Lanjutan Tabel 3/Continues Table 3

\begin{tabular}{|c|c|c|c|c|c|c|}
\hline \multirow[b]{2}{*}{ Peubah/ Variables } & \multicolumn{2}{|c|}{$\begin{array}{c}\text { Common Effect } \\
\text { Model }\end{array}$} & \multicolumn{2}{|c|}{$\begin{array}{l}\text { Fixed Effect } \\
\text { Model }\end{array}$} & \multicolumn{2}{|c|}{$\begin{array}{c}\text { Random Effect } \\
\text { Model }\end{array}$} \\
\hline & $\begin{array}{l}\text { Koefisien/ } \\
\text { Coefficent }\end{array}$ & $\begin{array}{c}\text { Nilai } \\
\text { Prob. I } \\
\text { Value of } \\
\text { Prob. }\end{array}$ & $\begin{array}{l}\text { Koefisien/ } \\
\text { Coefficent }\end{array}$ & $\begin{array}{c}\text { Nilai Prob/ } \\
\text { Value of } \\
\text { Prob. }\end{array}$ & $\begin{array}{l}\text { Koefisien/ } \\
\text { Coefficent }\end{array}$ & $\begin{array}{c}\text { Nilai } \\
\text { Prob/ } \\
\text { Value of } \\
\text { Prob }\end{array}$ \\
\hline $\begin{array}{l}\text { - Resultante Pertumbuhan } \\
\text { Penduduk + Pertumbuhan } \\
\text { Teknologi+ Penyusutan Modal } \\
\text { / Resultant from population } \\
\text { growth + technological } \\
\text { progress level + capital } \\
\text { depretiation level }\left((n+g+d)_{i t}\right)\end{array}$ & -0.0071 & 0.0354 & -0.0091 & 0.0514 & -0.0121 & 0.0327 \\
\hline $\mathrm{R}^{2}$ & 0.2813 & & 0.3150 & & 0.1631 & \\
\hline $\mathrm{R}^{2}$-adjust & 0.2615 & & 0.2709 & & 0.1310 & \\
\hline F-statistic & 14.1903 & & 7.1527 & & 7.0621 & \\
\hline Prob(F-stat.) & 0.0000 & & 0.0000 & & 0.0000 & \\
\hline DW & 1.5637 & & 1.5435 & & 1.7742 & \\
\hline $\begin{array}{l}\text { Kecepatan Konvergensi/ Speed } \\
\text { of Convergence, } \lambda(\%)\end{array}$ & 3.22 & & 8.50 & & 4.40 & \\
\hline Half-life $(\%)$ & 21.54 & & 8.16 & & 15.75 & \\
\hline Uji Chow/ Chow Test & \multicolumn{6}{|c|}{$\begin{array}{l}\text { Ho ditolak pada taraf } \alpha=0.05 / \mathrm{Ho} \\
\text { rejected at level } \alpha=0.05\end{array}$} \\
\hline Uji Housemen/ Housemen Test & & & \multicolumn{4}{|c|}{$\begin{array}{l}\text { Ho ditolak pada taraf } \alpha=0.05 / \mathrm{Ho} \\
\text { rejected at level } \alpha=0.05\end{array}$} \\
\hline
\end{tabular}

Sumber: Hasil pengolahan data/ Source: Output from data processing (2013)

Dengan kata lain, berdasarkan hasil pendugaan ketiga model tersebut disimpulkan bahwa telah terjadi proses konvergensi kondisional ekonomi wilayah pulau utama yang berbasis pesisir di Indonesia periode 1985-2010.

Di samping itu, ketiganya (hasil pendugaan dengan CEM, FEM dan REM) dari Tabel 3 memperlihatkan kecepatan proses konvergensi yang berbeda, masing-masing sebesar 3,22\% per tahun, $8,50 \%$ per tahun dan $4,40 \%$ per tahun; dan menghasilkan angka half-life yang juga berbeda, masing-masing selama 21,54 tahun, 8,16 tahun, dan 15,75 tahun. Tabel 3 juga memperlihatkan bahwa dengan menggunakan model FEM dalam pendugaan tendensi proses konvergensi ekonomi antar wilayah pulau utama yang berbasis pesisir di Indonesia, menghasilkan kecepatan konvergensi sebesar $8,50 \%$ per tahun yang lebih tinggi dibandingkan dengan menggunakan CEM (3,22\% per tahun); dan menghasilkan half-life selama 8,16 tahun yang lebih pendek dibandingkan dengan model CEM (21,54 tahun). Kemudian dengan menggunakan model random effect (REM) memperlihatkan hasil pendugaan dengan menggunakan model REM bahwa proses konvergensi ekonomi antar wilayah pulau utama yang berbasis pesisir di Indonesia berjalan dengan kecepatan konvergensi sebesar $4,40 \%$ per tahun dengan half-life selama 15,75 tahun.

Selanjutnya, pembahasan ini akan mengikuti hasil pendugaan model fixed effect (FEM) terutama untuk membandingkannnya dengan beberapa hasil penelitian sebelumnya. Hal ini karena berdasarkan hasil Uji Chow dan Uji Housmen yang menyimpulkan bahwa model fixed effect (FEM) lebih baik dibandingkan model common effect (CEM) dan model random effect (REM) sebagaimana terlihat pada Tabel 4.

Berdasarkan model FEM, seperti telah dijelaskan sebelumnya bahwa proses konvergensi ekonomi antar wilayah pulau utama yang berbasis pesisir di Indonesia berjalan dengan kecepatan konvergensi sebesar $8,50 \%$ per tahun dengan half-life selama 8,16 tahun. Hasil ini mendekati sama (mirip) dengan hasil penelitian lainnya di Indonesia, seperti hasil penelitian Garcia dan Soelistianingsih (1998) dengan periode 
pengamatan 1975-1993 menemukan tingkat kecepatan konvergensi sebesar 4,5\%; namun lebih rendah dibandingkan dengan hasil penelitian Firdaus (2011) yang diperoleh dengan menggunakan FEM untuk periode 1983-2003 menemukan kecepatan konvergensi sebesar $9,41 \%$ per tahun. Hasil ini lebih tinggi dari kecepatan konvergensi yang ditemukan Wibisono (2004) untuk periode 1984-2000 yang berkisar antara $0,51 \%$ hingga $1,83 \%$ dengan half-life convergence selama 38 hingga 136 tahun, namun keduanya bukan antar wilayah pulau utama yang berbasis pesisir melainkan untuk antar wilayah provinsi di Indonesia. Demikian pula bila hasil penelitian ini lebih tinggi dibandingkan dengan hasil penelitian Firdaus (2011), yang menyimpulkan bahwa berdasarkan SYS-GMM selama periode 1983-2003 ditemukan bahwa konvergensi pendapatan wilayah provinsi berlangsung lambat yaitu sebesar 0,29\% per tahun.

Hasil ini juga sesuai dengan beberapa penelitian sebelumnya yang menunjukkan tingkat konvergensi yang mendekati sama (mirip), terutama untuk lokus penelitian di luar negeri. Seperti hasil penelitian Bussoletti dan Espotti (2004) yang menghitung konvergensi pendapatan per kapita wilayah-wilayah negara di Eropa yang berada pada kisaran 5 sampai $7,5 \%$; dan hasil penelitian di Kanada yang memperoleh kecepatan konvergensi ekonomi wilayahnya pada kisaraan 6 sampai 6,5\% (Ralhan and Dayanandan, 2005). Di samping itu, hasil penelitian ini justru relatif lebih rendah juga dibandingkan hasil penelitian Cashin (2004) yang menunjukkan tingkat konvergensi di India sekitar 12,69\%. serta hasil penelitian De La Fuente (2000) yang menemukan kecepatan konvergensi di beberapa negara yang lebih tinggi dibanding hasil penelitian ini, yaitu selama 10\%-16,3\% per tahuan. Kecepatan tendensi proses konvergensi ekonomi wilayah pulau utama yang berbasis pesisir di Indonesia selama periode 1985-2010 yang berlangsung lambat dalam penelitian ini, terutama bila dibandingkan dengan hasil-hasil peneltian tersebut, menurut Firdaus (2011) dapat disebabkan oleh beberapa hal, yaitu: (1) Keberadaan decreasing return to scale dalam modal pada teknologi produksi yang tidak sepenuhnya memuaskan; (2) Perbedaan intensitas wilayah dalam menghasilkan atau mengadopsi teknologi baru; dan (3) Perbedaan tingkat perubahan struktural wilayah.

\section{Faktor-faktor Penentu Pertumbuhan Ekonomi Wilayah}

Berdasarkan persamaan yang sama dengan yang digunakan dalam melakukan pendugaan konvergensi kondisional ekonomi antar wilayah pulau utama yang berbasis pesisir di Indonesia selama periode 1985-2010, seperti dijelaskan di atas, sekaligus dapat pula diketahui faktor-faktor penentu yang mempengaruhi tingkat pertumbuhan ekonomi (pendapatan per kapita) wilayah tersebut. Selanjutnya, mengingat bahwa pendugaan faktorfaktor penentu pertumbuhan ekonomi wilayah dengan menggunakan model fixed effect (FEM) memberikan hasil yang dinilai terbaik, pembahasan faktor-faktor penentu pertumbuhan ekonomi wilayah tersebut mengikuti hasil pendugaan model FEM (Tabel 3). Hasil pendugaan ini memperlihatkan nilai koefisien determinasi $\left(R^{2}\right)$ sebesar 0,314982, yang berarti model mampu menjelaskan variasi pertumbuhan ekonomi (pendapatan per kapita) wilayah pulau utama yang berbasis pesisir di Indonesia sebesar $31,50 \%$. Sisanya sebesar $68,50 \%$ dijelaskan oleh peubah-peubah lainnya di luar model. Namun demikian, hasil uji serempak (uji F) dari ketiga model tersebut menujukkan bahwa secara bersama semua peubah tersebut berpengaruh nyata pada taraf $\alpha=0,01$.

Hasil pendugaan dengan menggunakan model fixed effect (FEM) juga menunjukkan tanda (sign) negatif pada koefisien parameter dari peubah investasi atau modal fisik $\left(S P M T D B_{i t}\right)$ dan nyata pada taraf $\alpha=0,01$. Tanda positif pada koefisien parameter ini sesuai dengan yang diharapkan atau konsisten dengan teori mengenai hubungan antara investasi dengan pertumbuhan ekonomi wilayah karena perannya dalam mendorong kapasitas produksi. Dengan besaran (magnitude) koefisien parameter peubah investasi fisik $\left(S P M T D B_{i t}\right)$ yang dihasilkan dari ketiga model tersebut sebesar 0,024995 yang berarti bahwa ceteris paribus, perubahan investasi fisik (akumulasi modal fisik) wilayah pulau utama yang berbasis pesisir di Indonesia meningkat sebesar 1\%, maka pertumbuhan ekonomi wilayah tersebut akan berubah meningkat sebesar 0,025\%. Temuan tersebut mengindikasikan bahwa selama periode 1985-2010, investasi fisik yang diukur berdasarkan rasio investasi fisik terhadap PDRB per kapita berperan penting bagi pembangunan wilayah pulau utama yang berbasis pesisir di Indonesia, khususnya melalui andilnya dalam 
mendorong kapasitas produksi yang meningkatkan pendapatan per kapita wilayah tersebut. Namun temuan ini harus dilihat lebih hati-hati mengingat ada kemungkinan efek positif ini merefleksikan efek balik dari pertumbuhan terhadap investasi, alih-alih investasi terhadap pertumbuhan (Wibisono, 2004).

Selanjutnya, dengan menggunakan model fixed effect (CEM) sebagaimana tertera pada Tabel 33, menunjukkan bahwa peubah investasi modal manusia atau akumulasi modal manusia $\left(H \cup C A P_{i t}\right)$ yang diukur berdasarkan rasio pekerja berpendidikan SLTA ke atas terhadap total pekerja berusia 15 tahun ke atas menunjukkan tanda (sign) yang positif dan nyata pada taraf $\alpha=0,01$. Tanda positif ini sesuai dengan yang diharapkan atau konsisten dengan teori bahwa peran kualitas sumberdaya manusia dalam meningkatkan produktivitas pekerja berhubungan positif dengan peningkatan pertumbuhan ekonomi. Besaran (magnitude) koefisien parameter peubah investasi modal manusia $\left(\mathrm{HUCAP}_{i t}\right)$ yang dihasilkan dari model fixed effect (FEM) sebesar 0,034126 yang berarti bahwa ceteris paribus, jika investasi modal manusia meningkat sebesar $1 \%$, maka pertumbuhan ekonomi dari wilayah pulau utama yang berbasis pesisir di Indonesia akan meningkat sebesar $3,41 \%$. Pengaruh positif dan nyata tersebut mencerminkan telah dimanfaatkannya kualitas pekerja dalam mendorong pertumbuhan ekonomi. Hal ini berkaitan pula dengan berkurangnya rigiditas (kekauan) pasar tenaga kerja yang menyebabkan elastiistas permintaan tenaga kerja yang meningkat, dan meningkatkan permintaan pekerja untuk setiap $1 \%$ pertumbuhan ekonomi (Chatib Bisri dalam Sufii, 2008).

Kemudian dari Tabel 3 diketahui bahwa hubungan antara peubah resultante pertumbuhan penduduk+pertumbuhan teknologi+penyusutan modal $\left((n+g+d)_{i t}\right)$ dengan peubah pertumbuhan ekonomi wilayah pulau utama yang berbasis pesisir di Indonesia selama periode 1985-2010 menunjukkan tanda (sign) atau arah yang negatif dan nyata pada taraf $\alpha=5 \%$. Tanda negatif ini sesuai dengan harapan atau konsisten dengan teori, khususnya dalam hubungan antara pertumbuhan penduduk $\left(n_{i t}\right)$ dan penyusutan modal $\left(g_{i t}\right)$ dengan pertumbuhan ekonomi. Dengan besaran (magnitude) koefisien parameter peubah resultante pertumbuhan penduduk+pertumbuhan teknologi+penyusutan modal $\left((n+g+d)_{i t}\right)$ yang dihasilkan dari ketiga model sebesar -0,009272 yang berarti bahwa ceteris paribus, jika peubah $(n+g+d)_{i t}$ wilayah pulau utama yang berbasis pesisir di Indonesia meningkat sebesar $1 \%$ maka akan menurunkan pertumbuhan ekonomi Indonesia sebesar -0,009\%. Hubungan yang negatif dan nyata dari koefisien parameter peubah $(n+g+d)_{i t}$ tersebut mengindikasikan bahwa peubah ini memiliki peran penting dalam pertumbuhan ekonomi (pendapatan per kapita) wilayah pulau utama yang berbasis pesisir di Indonesia. Namun demikian, hasil pendugaan hubungan antara peubah $(n+g+d)_{i t}$ dengan pertumbuhan ekonomi wilayah tersebut harus diartikan secara hati-hati terutama terkait dengan kebijakan yang harus diambil. Seperti dalam hal pertumbuhan penduduk $\left(n_{i t}\right)$ bisa terjadi disebabkan oleh arus migrasi masuk maupun kelahiran baru. Di samping itu, bertambahnya penduduk usia kerja, menuntut kenaikan porsi investasi dalam perekonomian yang diperlukan dalam menyediakan kebutuhan investasi bagi pekerja baru agar rasio kapital output tertap terjaga. Seandainya tidak terjadi pertumbuhan penduduk, maka kenaikan investasi dapat meningkatkan modal per pekerja dan mendorong pertumbuhan output per pekerja. Apabila pertumbuhan penduduk terjadi dari tingkat kelahiran yang tinggi, maka tingginya kelahiran tersebut akan mengurangi sumberdaya yang dapat digunakan untuk kegiatan produktif, yang akhirnya mengurangi output per kapita (Nanga, 2001).

\section{Kontribusi Penentu Pertumbuhan Ekonomi terhadap Kecepatan Konvergensi}

Analisis ini bertujuan untuk menduga kontribusi faktor penentu pertumbuhan ekonomi terhadap kecepatan proses kovergensi ekonomi wilayah pulau utama yang berbasis pesisir di Indonesia periode 1985-2010 yang dilakukan dengan menggunakan Uji Wald. Hasil Uji wald (pertama) menunjukkan bahwa dari ketiga model tersebut memutuskan untuk menolak Ho pada taraf $\alpha=0,01$ dan disimpukan bahwa koefisien peubah-peubah SPMTDB ${ }_{i t}$, HUCAP ${ }_{i t}$, dan $(n+g+d)$ it sebagai restriksi dalam persamaan regresi adalah berpengaruh nyata dalam model. Dengan demikian, jika peubah-peubah tersebut dikeluarkan dari persamaan akan mempengaruhi kecepatan proses konvergensi ekonomi wilayah pulau utama yang berbasis pesisir di Indonesia, baik yang diduga menggunakan CEM, FEM maupun REM. Kemudian hasil Uji Wald (kedua) memutuskan untuk menolak Ho dengan taraf $\alpha=0,01$ untuk setiap peubah yang diuji, sehingga terdapat perbedaan 
yang nyata dalam kecepatan proses konvergensi antara model kondisonal dengan model absolut. Dengan demikian disimpulkan bahwa faktor-faktor investasi fisik, modal manusia dan resultante pertumbuhan penduduk + perkembangan teknolog + pertumbuhan depresiasi kapital, secara sendiri dan bersama berpengaruh nyata terhadap tingkat kecepatan proses konvergensi ekonomi antar wilayah pulau utama yang berbasis pesisir tersebut, baik yang diduga menggunakan CEM, FEM maupun REM. Hasil perbandingan kecepatan proses konvergensi antara model lengkap (Tabel 2) dengan model tidak lengkap/ model restriksi (yang dihitung berdasarkan hasil uji pada Tabel 3), dapat dilihat pada Tabel 4. per tahun dan 2,74\% tahun; dan dengan half-life dari ketiga model tersebut menjadi lebih singkat (pendek) masing-masing selama 20,23 tahun, 10,34 tahun dan 31,76 tahun.

\section{KESIMPULAN DAN IMPLIKASI KEBIJAKAN}

\section{Kesimpulan}

Tendensi proses konvergensi ekonomi antar wilayah pulau utama di Indonesia selama periode 1985-2010 terjadi baik secara absolut maupun kondisional, masing-masing dengan kecepatan berkisar antara sebesar 1,66-3,75\% per tahun dan sebesar 3,22-8,50\% per tahun, yang terimplikasi dengan waktu yang dibutuhkan untuk mencapai

Tabel 4. Perbandingan Hasil Uji Konvergensi Ekonomi antar Wilayah Pulau utama di Indonesia antara Persamaan Konvergensi Absolut dengan Kondisional, 1985-2010.

Table 4. Comparation Output of Estimation on Economic Convergence Test among Main's Inland Regions in Indonesia between Absolute and Conditional Convergence Equations, 19852010.

\begin{tabular}{|c|c|c|c|c|c|c|}
\hline \multirow{2}{*}{$\begin{array}{c}\text { Kriteria Perbandingan/ } \\
\text { Comparation } \\
\text { Criterions }\end{array}$} & \multicolumn{3}{|c|}{$\begin{array}{l}\text { Persamaan Konvergensi Absolut/ } \\
\text { Absolute Convergence Equations }\end{array}$} & \multicolumn{3}{|c|}{$\begin{array}{l}\text { Persamaan Konvergensi Kondisional/ } \\
\text { Conditonal Convergence Equations }\end{array}$} \\
\hline & $\begin{array}{l}\text { Common } \\
\text { Effect Model }\end{array}$ & $\begin{array}{l}\text { Fixed } \\
\text { Effect } \\
\text { Model }\end{array}$ & $\begin{array}{c}\text { Random } \\
\text { Effect } \\
\text { Model }\end{array}$ & $\begin{array}{c}\text { Common } \\
\text { Effect } \\
\text { Model }\end{array}$ & $\begin{array}{l}\text { Fixed } \\
\text { Effect } \\
\text { Model }\end{array}$ & $\begin{array}{c}\text { Random } \\
\text { Effect Model }\end{array}$ \\
\hline $\begin{array}{l}\text { Koefisien Konvergensi/ } \\
\text { Coefficient fo } \\
\text { Convergence }\left(\beta_{1}\right)\end{array}$ & -0.0165 & -0.0368 & -0.0145 & -0.0317 & -0.0814 & -0.0434 \\
\hline $\mathrm{R}^{2}$ & 0.1522 & 0.3034 & 0.0473 & 0.2813 & 0.3150 & 0.1631 \\
\hline $\mathrm{R}^{2}$-adjust & 0.1465 & 0.2742 & 0.0409 & 0.2615 & 0.2709 & 0.1310 \\
\hline $\begin{array}{l}\text { Kecepatan Konvergensi } \\
\text { / Speed of Convergence } \\
\text { (\% per tahun/ per year) }\end{array}$ & 1.66 & 3.75 & 1.46 & $\begin{array}{r}3.22 \\
(1.56)\end{array}$ & $\begin{array}{r}8.50 \\
(4.75)\end{array}$ & $\begin{array}{r}4.40 \\
(2.74)\end{array}$ \\
\hline Half-life (tahun/ year) & 41.77 & 18.50 & 47.51 & $\begin{array}{r}21.54 \\
(20.23)\end{array}$ & $\begin{array}{r}8.16 \\
(10.34)\end{array}$ & $\begin{array}{r}15.75 \\
(31.76)\end{array}$ \\
\hline
\end{tabular}

Sumber: Hasil pengolahan data/ Source: Output from data processing (2013)

Keterangan/Remaks:

Angka di dalam kurung (...) menunjukkan perbedaan kecepatan konvergensi dan hafl-life time antara persamaan konvergensi kondisional dengan absolut/ Numbers in breakits (...) showed diference speed of convergence and half-life time between absolute and conditional convergence equations

Hasil perbandingan ini (Tabel 4) menunjukkan bahwa terdapat perbedaan kecepatan tendensi proses konvergensi antara persamaan konvergensi absolut) dengan model persamaan konvergensi kondisional, baik yang diduga dengan menggunakan CEM, FEM maupun REM. Dengan memasukkan peubah-peubah SPMTDB $B_{i t}$, HUCAP ${ }_{i t}$, dan $(n+g+d)_{i t}$ ke dalam persamaan akan menyebabkan kecepatan proses konvergensi ekonomi wilayah pulau utama yang berbasis pesisir di Indonesia berlangsung lebih cepat (bertambah) yang diduga menggunakan CEM, FEM dan REM, masing-masing sebesar $1,56 \%$ per tahun, $4,75 \%$ kondisi steady state dari perekonomian wilayah atau menurunkan setengah dari ketimpangan ekonomi wilayah menuju kondisi steady-state dari perekonomian wilayah (half-life) masing-masing berkisar selama 18,50-41,77 tahun dan selama 8,16-21,54 tahun. Sementara dengan mengontrol peubah-peubah penentu tingkat pertumbuhan ekonomi atau tingkat pendapatan steady-state (yaitu peubah-peubah akumulasi investasi, akumulasi modal manusia dan resultante pertumbuhan penduduk+perkembangan teknologi+depresiasi kapital), ternyata mampu mendorong kecepatan konvergensi dari bentuk absolut ke bentuk 
kondisional semakin cepat (bertambah) berkisar sebesar $1,56-4,75 \%$ per tahun. Peningkatan kecepatan konvergensi tersebut terilmplikasi dengan half-life yang semakin singkat (singkat) berkisar selama 10,34-31,76 tahun. Hal ini didukung oleh peubah-peubah akumulasi modal fisik (investasi), akumulasi modal manusia dan resultante pertumbuhan penduduk+perkembangan teknologi+depresiasi kapital menjadi penentu pertumbuhan ekonomi, sehingga peubah-peubah tersebut dinilai berperan penting dalam mendorong proses konvergensi ekonomi wilayah pulau utama di Indonesia menjadi semakin cepat dengan half-life yang semakin singkat.

\section{Implikasi Kebijakan}

Temuan penelitian menunjukkan bahwa tendensi proses konvergensi ekonomi wilayah pulau utama di Indonesia selama periode 1985-2010 yang diantaranya dibandingkan dengan beberapa negara berkembang lainnya menunjukkan telah berlangsung secara lambat, dan hal ini berhubungan dengan faktor-faktor penentu pertumbuhan ekonomi wilayah yang turut mendorong kecepatan konvergrnsi tersebut. Dengan kata lain, konvergensi tersebut berhubungan dengan tingkat investasi yang rendah baik pada modal fisik maupun modal manusia di wilayah-wilayah pulau utama yang berbasis pesisir yang miskin atau kurang maju. Lebih jauh lagi, ketidakmampuan melakukan investasi ini membuat kelemahan wilayah-wilayah pulau utama yang berbasis pesisir yang miskin atau kurang maju tersebut menjadi berlipat-ganda karena kehilangan peluang investasi untuk mengejar (cathing-up) ketertinggalannya melalui akumulasi faktor (investasi modal fisik dan modal manusia) dan juga karena kehilangan peluang membangun kapabilitas teknologi melalui pendidikan (investasi modal manusia) yang akan menfasilitasi transfer teknologi. Oleh karena itu, dibutuhkan keterlibatan pemerintah pusat maupun daerah yang lebih nyata dalam mendorong pertumbuhan ekonomi wilayah pulau utama di Indonesia yang mampu mempercepat proses konvegensi ekonomi antar wilayah tersebut. Keterlibatan tersebut dapat dilakukan dalam bentuk kebijakan-kebijakan yang meningkatkan akumulasi investasi modal fisik dan akumulasi investasi modal manusia, serta pengendalian pertumbuhan penduduk depresiasi modal, namun masih mendorong tingkat perkembangan teknologi, terutama untuk wilayah-wilayah pulau utama yang tertinggal atau kurang maju. Mengingat bahwa wilayah-wilayah pulau utama di Indonesia --terutama di Kawasan Timur Indonesia memiliki sumberdaya kelautan yang besar--, maka pada tahap formulasi dan implementasi, kebijakan-kebijakan tersebut perlu mempertimbangkan peran kelautan di Indonesia yang disinergikan dengan upaya meningkatkan interrelasi atau konektivitas yang mampu menciptakan ketergantungan ekonomi sektoral dan spasial antar wilayah di Indonesia. Komitmen pemerintah untuk mengkonsentrasikan kegiatan ekonomi ke KTI termasuk dalam bidang kelautan perlu dilengkapi dengan upaya mempertahankan laju pertumbuhan ekonomi.

\section{DAFTAR PUSTAKA}

Adisasmita, R. 2008. Ekonomi Archipelago. Graha IImu. Yogyakarta.

Amstrong, H. and J. Taylor. 2001. Regional Economic and Policy. Third Edition. Blackwell Publisher. UK.

Balisacan, A.M. and N. Fuwa. 2003. Growth, Inequality and Politics Revisited: A developing-Country Case. Economics letters. 79: 53-58.

Barro, R., and X. Sala-i-Martin. 1991. Convergence across states and regions, Brookings Papers on Economic Activity. 1 : 107-182.

Barro, R. J. 1994. Economic Growth and Convergence. An International Center for Economic Growth Publication. California Press. San Francisco.

Barro, R.J. and X, Sala-I-Martin. 1995. Economic Growth. New York. McGraw-Hill Inc. USA.

Baumol, W.J. 1986. Productivity Growth, Convergence, and Welfare: What the Long-Run Data Show, American Economic Review. 76: 1072-1085.

Bernard, A. and C. Jones. 1996. Productivity and convergence across U.S. States and industries, Empirical Economics. 21: 113-135.

Bond, S., A. Hoeffler, and J, Temple. 2001. GMM estimation of empirical growth models, CEPR discussion paper no. 3048. Centre for Economic Policy Research, London.

Bussoletti, S., and R. Espoti. 2004. Regional Convergence, Structural Funds and the Role of Agriculture in the EU: A Panel Data Approach. Universit Politecnica Dell Marche. Dipartimento Di Economia. Quarderno Di Ricerca. No. 220. 
De La Fuente, A. 2000. Convergence Across Countries and Regions: Theory and Empiris. Barcelona, Instituto de Analisis Economico. Vol 5(2).

Donbusch, R., S. Fisher, and R. Starrz. 2001. Macroeconomics. McGraw Hill Education. New York, USA.

Dowrick, S. and M. Rogers. 2001. Classical and Technological Convergence: Beyond the Solow-Swan model. Australian National University.

Dowrick, S. and Rogers, M. 2002. Classical and Technological Convergence: Beyond the Solow-Swan Model. Oxford Economic Papers. 54 (3): 369-385.

Firdaus, M. 2011. Aplikasi Ekonometrika untuk Data Penel dan Time Series. IPB Press. Bogor.

Garcia, G.J. and L. Soelistianingsih. 1998. Why Do Differences in Provincial Income Persist in Indonesia?. Bulletin of Indonesian Economic Studies. Vol 34 (1): 95-120.

Green, W.H. 2000. Econometric Anlysis. Prentice-Hill. USA.

Gundlach, E. 1997. Regional Convergence of Output per Worker in China: A Neoclssical Interpretation. Asian Economic Journal. 11: 432-442.

Islam, N. 1995. Growth Empirics: A Panel Data Approach, Quarterly Journal of Economics. Vol 110(4): 1127-1170.

Jian, T., J.Sachs, , and A. Warner. 1996. Trends in Regional Inequality in China. National Bureau of Economic Research Working paper, No. 5412.

Juanda, B. dan Junaidi. 2012. Ekonometrika Deret Waktu: Teori dan Aplikasi. IPB Press. Bogor.

Kuncoro, M. 2004. Pertumbuhan Ekonomi dan Ketimpangan Antar Wilayah dalam buku Otonomi Dan Pembangunan Daerah. Penerbit Erlangga. Jakarta.

Long, J. S. 1997. Regression Models for Categorical and Limited Dependent Variables. Advanced Quantitative Techniques in the Social Science. SAGE Publication, Inc. USA.

Mankiw, N. G. 2003. Teori Makroekonomi Edisi Kelima. Terjemahan. Penerbit Erlangga. Jakarta.
Mankiw, N.G., D. Romer, and D.N Weil. 1992. A Contribution to the Empirics of Economic Growth. The Quarterly Journal of Economics. 107: 407-437.

Nanga, M. 2001. Makroekonomi: Teori, Masalah dan Kebijakan. Edisi Perdana. Rajawali Press. Jakarta.

Ralhan, M. and A. Dayanandan. 2005. Convergence of Income Among Provinces in Canada - An Application of GMM Estimation. Econometrics Working Paper EWP-0502: 13-21.

Romer, P.M. 1996. Idea Gaps and Object Gaps in Economic Development. Journal of Monetary Economics. 32: 543-574.

Sala-i-Martin, X. 1996. Regional Cohesion: Evidence and Theories of Regional Growth and Convergence, European Economic Review. 40: 1325-1352.

Serra, M.I. 2006. Regional Convergence in Latin America. IMF Working Paper, No. 06/125 May 01.

Sirojuzilam. 2009. Disaparitas Ekonomi Regional dan Perencanaan Wilayah. Pidato Pengukuhan Guru Besar Tetap dalam Bidang Ilmu Ekonomi Regional. Universitas Sumatera Utara.

Sufii, S. 2008. Konvergensi Ekonomi Regional di Indonesia Tahun 1985-2006. Thesis. Fakultas Ekonomi. Program Magister Perencanaan dan Kebijakan Publik. Universitas Indonesia. Jakarta.

Vidyattama, Y. 2006. Regional Convergence and Indonesia Economic Dynamic. Economic and Finance in Indonesia. EFI. 2 - 2006: 197-228.

Wibisono, Y. 2004. Sumber-Sumber Pertumbuhan Ekonomi Regional, 1984-2005. Program Pascasarjana, Fakultas Ekonomi, Universitas Indonesia. Depok.

Widarjono, A. 2007. Ekonometrika: Teori dan Aplikasi untuk Ekonomi dan Bisnis. Edisi Kedua. Penerbit Ekonisia, Fakultas Ekonomi UII. Yogyakarta. 